\title{
The Determinant of Budget Fiscal Deficit of the Palestinian Authority and the Economic Factors Affecting It
}

\author{
Khaled Hasan Zubdeh ${ }^{1}$ \\ ${ }^{1}$ Faculty of Administrative and Economic Sciences, Al-Quds Open University, Palestine \\ Correspondence: Khaled Hasan Zubdeh, Faculty of Administrative and Economic Sciences, Al-Quds Open University, \\ Palestine.
}

Received: April 1, 2021

Accepted: May 6, 2021

Online Published: May 19, 2021

doi:10.5430/rwe.v12n3p63

URL: https://doi.org/10.5430/rwe.v12n3p63

\begin{abstract}
A prolonged fiscal deficit is an inheriting problem for the Palestinian economy. This leaves the Palestinian authorities unable to pay for salaries and other needed money to spend on the infrastructure, education, health, and other services. The main aim of this study is to examine the relationship between the budget deficit and some indicators, gross domestic product, balance of trade, inflation rate, unemployment rate, and current account, using ordinary least square and ARMA methods for collected quarterly data for the years 2000-2018, and applying the data to a number of other tests such as unit roots test, Johansen cointegration test, normal distribution test, heteroskedasticity test, Breusch-Pagan-Godfrey, variance inflation factors, etcetera, using Eviews10 program. The study's main findings showed a long-run cointegration relationship between the budget deficit and the independent variables included in the study. The gross domestic product, balance of trade, and unemployment rate have a significant negative relationship with the budget deficit, while the remaining variables, inflation rate and current account, have a significant positive relationship with budget deficit.
\end{abstract}

Keywords: budget, deficit, dickey-fuller, Palestinian authority

\section{Introduction}

One of the most important problems facing developed and developing countries is the fiscal deficit in the budget and its negative economic consequences. Many Countries find it difficult to address these consequences and minimize their impact on the country's economic indicators.

The Palestinian Authority areas are the best example of the low economic resources needed to establish infrastructure projects, where the political instability in the region does not create an attractive investment environment. Add to this, the absence of a national currency causing high inflation rates, the existence of unjust economic agreements with the Israeli side such as the Paris Economic Agreement of 1994 (the Paris Protocol), and the deliberate failure of the Israeli side to comply with its provisions, which affected the tax revenues necessary to finance the general budget, especially the clearing revenues. These are the causes why the Palestinian Authority has always suffered from budget deficit since the signing of the Oslo Accords with the Israeli side in 1993. The Palestinian Authority still depends on foreign aid to finance the budget deficit despite its attempts to rely more on local alternatives in funding and reducing the relative importance of foreign aid and grants (Palestine Monetary Authority, 2012).

The economic theories tried to emphasize the relationship between the budget's financial fiscal and the economic factors like the gross domestic product (GDP), foreign direct investment, inflation rate, exchange rate, and unemployment rate. Therefore, the researcher tries to examine the relationship between the budget fiscal deficit and the economic factors.

\section{Statement of the Problem}

Going through the Palestinian general budget for the years 2000-2018, we found that Palestine suffered fiscal deficit before grants and aids, as shown in Table 1, due to the high rate of government overheads, especially for current expenditures after the donors retreated from their promises and the detention of clearing funds by the Israeli side, which constitutes $60.05 \%$ of the Palestinian Authority's total revenues (MAS, 2019). This caused the deepening of the Palestinian Authority's fiscal deficit. 
Many studies emphasized the effect of budget deficit on the rate of macroeconomic factors and growth rate. In this study, we are going to examine the relationship between the chronic prolonged budget deficit of the Palestinian Authority and the economic indicators such as gross domestic product, inflation rate, exchange rate, foreign direct investment, unemployment rate, current account, and gross capital formation.

Table 1. Budget deficit before grants and aid (2000-2018) (Million Dollars)

\begin{tabular}{lclllllllll}
\hline Year & $\mathbf{2 0 0 0}$ & $\mathbf{2 0 0 1}$ & $\mathbf{2 0 0 2}$ & $\mathbf{2 0 0 3}$ & $\mathbf{2 0 0 4}$ & $\mathbf{2 0 0 5}$ & $\mathbf{2 0 0 6}$ & $\mathbf{2 0 0 7}$ & $\mathbf{2 0 0 8}$ & $\mathbf{2 0 0 9}$ \\
\hline $\begin{array}{l}\text { Budget Fiscal } \\
\text { Deficit }\end{array}$ & 400 & 952 & 914 & 765 & 817 & 911 & 985 & 1261 & 1708 & 1827 \\
\hline Year & $\mathbf{2 0 1 0}$ & $\mathbf{2 0 1 1}$ & $\mathbf{2 0 1 2}$ & $\mathbf{2 0 1 3}$ & $\mathbf{2 0 1 4}$ & $\mathbf{2 0 1 5}$ & $\mathbf{2 0 1 6}$ & $\mathbf{2 0 1 7}$ & $\mathbf{2 0 1 8}$ & \\
\hline $\begin{array}{l}\text { Budget Fiscal } \\
\text { Deficit }\end{array}$ & 1358 & 3857.8 & 3894.3 & 3981.4 & 2909.9 & 710.9 & 324.7 & 390.2 & 468.6 &
\end{tabular}

Source: Palestinian Monetary Authority, different annual reports (2000-2013), and economic monitor (2014 -2018)

\section{Literature Review}

Maio, Francis, and Venkatesh (2018) tried to examine the role of budget deficits as a contributor to inflation in Zambia. An econometric analysis was carried out using the autoregressive distributed lag (ARDL) approach. The analysis showed that while there are significant short-run impacts of deficits on inflation, no significant long-run relationship existed.

UNCTAD (2017) showed that the Israeli military, political and economic measures in the occupied Palestinian territories resulted in a huge resource gap, whereby domestic absorption, including domestic consumption and investment, both public and private, exceeds domestic production by a substantial amount. This study demonstrated that the Palestinian trade deficit is not driven by the budget deficit, using the Granger causality test, which disproves the hypothesis that changes in the trade deficit were caused by changes in the budget deficit, as presumed under the twin deficits hypothesis. As for addressing the Palestinian resources gap, the study suggests taking measures like rehabilitating the Palestinian productive capacity and narrowing the difference between the total number of the Palestinian labor force and the number of workers employed in the domestic economy. However, under the conditions created and reinforced by the occupation, all attempts to reduce the resource gap by narrowing one of the two differences failed, and the main impact of a reduction in the Palestinian budget deficit would be an increase in unemployment and a reduction in the trade deficit. This study proposes a two-pronged strategy of reform and growth to bridge the resource gap. Growth needs to be pursued by expanding the agricultural sector, expanding the manufacturing sector, and adopting a national strategy of technological development.

Fakher (2016) investigated the effects of the budget deficit on broad money supply, real GDP, import price index, interest rate, exchange rate, and rate on inflation (price deflator) in selected Asian economics, namely China, Japan, Korea, India, Taiwan, and Singapore in the periods 1993-2013. By applying the pooled mean group (PGM) estimation-based error correction model and the panel differenced (generalized method of moments) Arellano-Bond estimator, the study found that the budget deficit, real GDP, and exchange rate are statistically significant determinants of inflation in both methods of estimation.

Magehema (2015) study sought to establish the effect of budget deficit on East African countries' economic development. The factors identified in the study are the budget deficit rate, interest rate, inflation rate, and foreign exchange. He used quantitative data in the form of secondary data from Tanzania, Kenya, Uganda, Rwanda, and Burundi over ten years from 2004 to 2013. The multi-variety linear regression was conducted on the countries, and the findings had a positive relationship in all countries. The researcher concluded that the effect of budget deficit on economic development depends on how the funds financing the deficit are used. If they were used for development purposes, it would have had a positive relationship, but if used to meet the recurrent expenditures, there would be a negative relationship between the two.

Nguyen (2015) investigates the effects of the fiscal deficit and broad money M2 supply on inflation in Asian countries, namely Bangladesh, Cambodia, Indonesia, Malaysia, Pakistan, Philippines, Sri Lanka, Thailand, and Vietnam in the period of 1985-2012. By applying the PMG estimation-based error correction model and the panel differenced GMM (generalized method of moments) Arellano-Bond estimator, the study found that the broad money M2 supply has a significantly positive impact on inflation only in the method of PMG estimation. In contrast, fiscal 
deficit, government expenditure, and interest rate are statistically significant determinants of inflation in both methods of estimation.

Abu Alqumsan (2015) study aimed to determine the fiscal deficit's economic factors in the Palestinian Authority's general budget during 1995-2013. The study used the descriptive-analytical method and the quantitative standard method for the construction of the standard model, using deficit before grants and aid to GDP "dependent variable" and chose some economic variables, "independent variables", namely: current account ratio to GDP, the rate of investment, the unemployment rate, the rate of inflation, the price of foreign exchange, as well as political factors. The study found a significant positive relationship between each of the independent variables to GDP, while a negative relationship was found between the current account ratio to GDP and the inflation rate and foreign exchange rate to GDP.

A study conducted by Goher, Mehboob, and Wali ( 2012) aimed to investigate the budget deficit's true impact on Pakistan's economic growth. The sample taken for the study comprised a time-series considering the period of 1978-2009. Regression analysis is conducted to ascertain budget deficit's impact on the GDP and explore the negative impact of budget deficit on economic growth. Some policies are suggested for the government to avoid certain levels of the budget deficit to achieve the desired level of growth.

Buscemi and Yallwe (2012) analyzed, in their study, the effects of fiscal deficit on the sustainability of economic growth and provided new empirical evidence on the effects of fiscal deficit on saving and sustainability of economic growth based on the assumption of the endogenous growth model. They estimated using the reduced form of GMM method for dynamic panels covering the years 1990-2009 for three emerging countries: China, India, and South Africa.

Abu Zaiter (2012) study aimed to identify the sources of funding for the Palestinian budget in general and the local ones in particular, also the significance of each of them and their role in the financing of public expenditure in the period 2000-2010, in addition to highlighting the impact of trade and economic agreements signed by the Palestinian Authority with other countries on the local revenues. The study indicated that the Palestinian Authority applied items budget, not the programs and performance budget. The rate of development expenditure to public expenditure was $12 \%$, while current expenditures were $77 \%$, where more than $60 \%$ of it was channeled toward salaries and wages. The study also found that more than $77 \%$ of the trade exchange volume to the Palestinian Authority accounted for Israel, which means that Israel controlled more than $64 \%$ of local revenues for the Palestinian Authority.

Abu Mustafa (2009) tried to analyze the role and importance of external financing to cover the deficit of the Palestinian National Authority's budget for the period from 1999-2008. The main results of the study are as follows: There is a statistically significant relationship between the deficit as a dependent variable and the salaries, wages, manufacturing costs, grants, and soft loans; in addition, there is an absence of a statistically significant relationship between deficit and the operational expenses, development expenses and the local public income.

Vuyyuri and Venkata (2004) study tried to study the interaction of the budget deficit of India with other macroeconomic variables such as nominal effective exchange rate, GDP, consumer price index, and money supply (M3), giving special emphasis on the budget deficit-exchange rate relationship using the cointegration approach and the variance error correction models (VECM) for the period 1970-2002. The results revealed that the study variables are cointegrated, and there is bi-directional causality between budget deficit and nominal effective exchange rates. However, they have not observed any significant relationship between budget deficit and GDP, money supply, and consumer price index. It is also observed that the GDP Granger causality causes budget deficit, whereas the budget deficit does not.

Aljafri and Alardah (2002) study attempted to shed light on the Palestinian financial and trade policies and clarify their responsibility for the exacerbation of the deficit in the public budget and the deficit in the trade balance, despite the success of Palestinian trade policies in increasing the volume of trade exchange with the outside world. However, this did not contribute to reducing commercial dependence on Israel, which led to an increase in the relative importance of consumer goods, reaching $80 \%$ of imports, which contributed to the exacerbation of the trade balance deficit. In addition, Israeli closures, which led to a decrease in remittances from workers in the Israeli economy, played a major role in financing the trade balance deficit. Government spending policies have also contributed to the exacerbation of the trade deficit and the budget deficit through the excessive increase in government employment to solve the rise in the unemployment problem, as salaries acquired $60 \%$ of the total public spending. Among the most important recommendations of this study is the attempt to affect GDP's value and components by raising the rates of value-added tax and purchase tax on imported goods, reducing tax rates on domestic products, supporting exports, and increasing their competitiveness. 
Darrat (1988) study proved that the causal relationship between the general budget deficit and the American current account deficit during the period 1824-1821 emphasized the existence of a two-way causal relationship consistent with the research hypothesis. The growth of the monetary base and the rise in interest rates has played a role in the increase in the current account deficit. On the contrary, real income has no role in the increase in the trade deficit and the role of the current account deficit, including interest rates, wage costs, the monetary base, and real output; and inflation has a large role in influencing the federal budget deficit.

As we have noticed, all previous studies conducted in countries with stable economy without restrictions imposed from outside factors, such as Palestine, which mostly depends on clearing revenues from the Israeli side to finance its budget deficit, add to that the fact that the Palestinian economy is confined by the Paris Economic Agreement (1994) which controls the Palestinian economy. It's worth mentioning that the Palestinian Authority is still dependent on foreign aids to finance its activities.

\section{Present Financial Situation of the Palestinian Authority}

After signing the Oslo Accord in 1993, successive Palestinian governments have done their best to restructure the Palestinian economy. The Palestinian Authority has made major reforms in its system in line with the international standards, particularly its ability to control and rationalize its expenditures, reduce reliance on foreign grants and assistance, and strengthen the self-capabilities to implement the principle of self-reliance and financial stability.

The Palestinian Authority's financial situation has been linked to foreign aid and the political and economic relationship with the Israeli side, which in turn has affected the revenues and expenditures of the Palestinian Authority.

The flow of foreign aid went through two major phases: The first phase followed the Oslo Accord, and the pattern of assistance was stable. The European Union (EU), the United State of America (USA), and Japan topped the donors' list during the period 1994-2000, with a value of US \$3863 million for the implementation of the peace agreement between the Palestinian Authority and Israel. While the second phase was characterized by many fluctuations after the setback in the peace process and due to the unrest situations, in which the Arab and Islamic countries topped the donors' list, which amounted to US \$11116 million in the period 2006-2011. International aid becomes an important source of economic activity, contributing an average of $15.8 \%$ of GDP during 1994-2000 and 20.1\% of GDP in 2001-2011 (Alshaikh, 2012).

Whereas the volume of grants and foreign aid in 2012 was about 63586 million shekels, compared to 33520 million shekels in the previous year, which formed $9.1 \%$ of the GDP.

The year 2014 witnessed a significant decline in the amount of grants and aid by $4.10 \%$ compared to the previous year, which formed about $9.6 \%$ of the GDP.

The volume of foreign aid and grants continued to decline in the following sixth years. In 2018, it reached an estimate of $1.7 \%$ compared to the previous year. It amounted to 64112 million shekels as it reached $4.6 \%$ of Palestinian GDP (Palestinian Monetary Reports, 2012-2018).

Throughout 2018, the Palestinian Authority's efforts to reduce the budget deficit continued through public finance management reform and public expenditure rationing, including the preparation of locally-owned private spending plans.

It has also increased and enhanced revenues through improved tax collection methods, the continuation of a stimulating and reduced tax policy, and the continued monitoring, development, and improvement of clearance mechanisms with Israel (Palestinian Monetary Report, 2018).

To understand the Palestinian Authority's financial position, let us look at the published data in the Palestinian Monetary report regarding the total revenues and expenditure during the financial year 2018. We notice that the year 2018 witnessed a significant decline in the clearance revenue, accompanied by a decrease in grants against a rise in domestic revenue (tax and non-tax), which resulted in a decline in public revenues and grants by about $4.1 \%$ compared to the previous year. After deducting the tax refund, the net public revenue and grants decreased by 6.2 percent in 2018 to reach new Israeli Shekels (NIS) 14819.3 million. Meanwhile, the public expenditure decreased by $3.2 \%$ compared to the previous year, to NIS 14137.1 million, mainly due to lower wages and salaries.

Developments in both sides of the public finances during 2018 led to a significant increase in the current deficit (on a cash basis) to about NIS 726.3 million compared to a deficit of NIS 486.8 million in 2017. This is mainly due to lower public revenues (clearance revenue in particular) at a rate higher than current expenditure and net lending.

The overall balance before the grants deficit (including development expenditures) increased to NIS 1729.4 million compared to a deficit of NIS 1408.1 million in 2017. Before the financial support, the total deficit was about $3.3 \%$ of the GDP compared to 2.7\% in 2017 (Palestinian Monetary Report, 2018). 


\section{Hypothesis}

In order to analyze the relationship between the budget deficit and other economic factors, the researcher examined the following:

HO: There is no statistically significant relationship at $\alpha \leq 0.05$ between budget deficit (BUDF) and economic indicators: Gross domestic product (GDP), balance of trade (BOT), inflation rate (INF), unemployment rate (UNP), and current account (CRA) in Palestine.

H1: There is a statistically positive/negative significant relationship at $\alpha \leq 0.05$ between budget deficit (BUDF) and economic indicators: Gross domestic product (GDP), balance of trade (BOT), inflation rate (INF), unemployment rate (UNP), and current account (CRA) in Palestine.

\section{Data and Methodology}

This study utilized the annual time-series data of the budget deficit (BUDF), gross domestic product before grants and aid (GDP), balance of trade (BOT), inflation rate (INF), unemployment rate (UNP), and current account (CRA) obtained from the official publications of the Palestinian Central Bureau of Statistics, the Palestinian Monetary Authority and the Ministry of Finance and Planning covering the sample period from 2000 to 2018. The covered period was converted into quarterly data from the first quarter of 2000 to the fourth quarter of 2018 with a sample including 76 observations.

The study's main goal is to find whether there is a relation between the BUDF and GDP, BOT, INF, UNP, and CRA. Thus, the ordinary least square (OLS) method and ARMA maximum likelihood were used for estimating the econometric model, using Eviews10 program. Consequently, unit roots and cointegration tests should be administrated first, then other tests are conducted.

\section{Suggested Econometric Model}

In order to analyze the relationship and the effect of economic indicators on fiscal deficit, we suggested an econometric function, which is presented in the following equation:

$$
\mathrm{BUDF}=\beta_{0}+\beta_{1}(\mathrm{GDP})+\beta_{2}(\mathrm{BOT})+\beta_{3}(\mathrm{INF})+\beta_{4}(\mathrm{UNP})+\beta_{5}(\mathrm{CRA})+\varepsilon_{\mathrm{t}}
$$

Where:

$\beta_{0}$ : Constant Term

$\beta_{1}, \beta_{2}, \beta_{3}, \beta_{4}, \beta_{5}$ : Regression coefficients for independent variables.

$\varepsilon_{\mathrm{t}}$ : Random error.

Where BUDF denotes budget deficit, GDP is gross domestic, BOT is balance of trade, INF is inflation rate, UNP is unemployment rate, CRA is current account, and finally $\varepsilon_{t}$ is random error term.

\section{Empirical Analysis}

\subsection{Testing for Unit Roots Using Augmented Dickey-Fuller (ADF) and Philips-Perron Tests}

To investigate the order of integrated variables included in the study, the researcher used the augmented Dickey-Fuller (ADF), Philips-Perron (PP) tests, and the null hypothesis "the variable has a unit root". As we notice from Table 2, the entire variable is stationary at first difference and integrated at the same order.

Table 2. Unit root test results table (PP\&ADF)

\begin{tabular}{|c|c|c|c|c|c|c|}
\hline \multicolumn{7}{|c|}{ UNIT ROOT TEST TABLE (PP) } \\
\hline & \multicolumn{6}{|l|}{ At Level } \\
\hline & & BUDF & GDP & CRA & INF & UNP \\
\hline \multirow[t]{3}{*}{ With Constant } & t-Statistic & -1.5732 & 0.3553 & -1.9313 & -3.0953 & -3.0425 \\
\hline & Prob. & 0.4912 & 0.9797 & 0.3165 & 0.0312 & 0.0355 \\
\hline & & n0 & n0 & n0 & $* *$ & $* *$ \\
\hline \multicolumn{7}{|l|}{ With Constant } \\
\hline \multirow[t]{3}{*}{$\&$ Trend } & $\mathrm{t}$-Statistic & -1.3277 & -2.659 & -2.6119 & -3.634 & -3.0146 \\
\hline & Prob. & 0.8733 & 0.2564 & 0.2765 & 0.0336 & 0.1352 \\
\hline & & n0 & n0 & n0 & $* *$ & n0 \\
\hline
\end{tabular}




\begin{tabular}{|c|c|c|c|c|c|c|}
\hline Without Constant & & & & & & \\
\hline \& Trend & $\mathrm{t}$-Statistic & -0.9431 & 2.6721 & -0.7109 & -1.9145 & 0.602 \\
\hline & Prob. & 0.3052 & 0.998 & 0.4055 & 0.0535 & 0.8443 \\
\hline & & n0 & n0 & n0 & $*$ & n0 \\
\hline & At First D & rence & & & & \\
\hline & & $\mathrm{d}(\mathrm{BUDF})$ & $\mathrm{d}(\mathrm{GDP})$ & $\mathrm{d}(\mathrm{CRA})$ & $\mathrm{d}(\mathrm{INF})$ & $\mathrm{d}(\mathrm{UNP})$ \\
\hline With Constant & $\mathrm{t}$-Statistic & -8.4853 & -9.6623 & -8.4995 & -8.491 & -8.6077 \\
\hline & Prob. & 0 & 0 & 0 & 0 & 0 \\
\hline & & $* * *$ & $* * *$ & $* * *$ & $* * *$ & $* * *$ \\
\hline With Constant & & & & & & \\
\hline \& Trend & $\mathrm{t}$-Statistic & -8.5517 & -9.7622 & -8.4489 & -8.4453 & -8.5814 \\
\hline & Prob. & 0 & 0 & 0 & 0 & 0 \\
\hline & & **** & $* * *$ & **** & $* * *$ & **** \\
\hline Without Constant & & & & & & \\
\hline$\&$ Trend & $\mathrm{t}$-Statistic & -8.544 & -8.544 & -8.544 & -8.544 & -8.544 \\
\hline & Prob. & 0 & 0 & 0 & 0 & 0 \\
\hline & & $* * *$ & $* * *$ & $* * *$ & $* * *$ & $* * *$ \\
\hline & UNIT RO & TEST TA & (ADF) & & & \\
\hline & At Level & & & & & \\
\hline & & BUDF & GDP & CRA & INF & UNP \\
\hline With Constant & t-Statistic & -1.5328 & -0.4791 & -1.8473 & -1.4315 & -3.0266 \\
\hline & Prob. & 0.5117 & 0.8884 & 0.3552 & 0.5621 & 0.0369 \\
\hline & & n0 & n0 & n0 & n0 & $* *$ \\
\hline With Constant & & & & & & \\
\hline \& Trend & t-Statistic & -1.3135 & -2.4752 & -2.4886 & -2.6897 & -3.0146 \\
\hline & Prob. & 0.877 & 0.3392 & 0.3329 & 0.244 & 0.1352 \\
\hline & & n0 & n0 & n0 & n0 & n0 \\
\hline Without Constant & & & & & & \\
\hline \& Trend & t-Statistic & -0.9376 & 1.236 & -0.7017 & -0.9266 & 0.2464 \\
\hline & Prob. & 0.3074 & 0.9436 & 0.4096 & 0.3118 & 0.7549 \\
\hline & & n0 & n0 & n0 & n0 & n0 \\
\hline & At First D & rence & & & & \\
\hline & & $\mathrm{d}(\mathrm{BUDF})$ & $\mathrm{d}(\mathrm{GDP})$ & $\mathrm{d}(\mathrm{CRA})$ & $\mathrm{d}$ (INF) & $\mathrm{d}(\mathrm{UNP})$ \\
\hline With Constant & t-Statistic & -8.4853 & -2.5115 & -8.4995 & -8.6103 & -8.6077 \\
\hline & Prob. & 0 & 0.117 & 0 & 0 & 0 \\
\hline & & $* * *$ & n0 & $* * *$ & $* * *$ & $* * *$ \\
\hline With Constant & & & & & & \\
\hline \& Trend & $\mathrm{t}$-Statistic & -8.5518 & -2.3171 & -8.4489 & -8.6856 & -8.5814 \\
\hline & Prob. & 0 & 0.4193 & 0 & 0 & 0 \\
\hline & & $* * *$ & n0 & $* * *$ & $* * *$ & $* * *$ \\
\hline Without Constant & & & & & & \\
\hline \& Trend & $\mathrm{t}$-Statistic & -8.544 & -1.6264 & -8.544 & -8.6695 & -8.544 \\
\hline & Prob. & 0 & 0.0976 & 0 & 0 & 0 \\
\hline & & $* * *$ & $*$ & $* * *$ & $* * *$ & $* * *$ \\
\hline
\end{tabular}

Notes: $(*)$ Significant at the $10 \% ;(* *)$ Significant at the 5\%; (***) Significant at the 1\%. and (no) Not Significant Source: calculated from data using Eviews 10 program 


\subsection{Johansen Cointegration Test}

Since variables are first difference stationary, then the Johansen cointegration test is appropriate for this study to determine the existence of a long-run relationship between the variables in the model. Thus, we have used the Johansen test-Trace statistics-to solve bi-directional causality problems and consider all variables endogenous to the system. In other words, we intend to calculate two likelihood ratio criteria to test the number of cointegration vectors in the model.

Table 3. Johansen cointegration test

\begin{tabular}{|c|c|c|c|c|}
\hline \multicolumn{5}{|c|}{ Sample (adjusted): 2000Q4 2018Q1 } \\
\hline \multicolumn{5}{|c|}{ Included observations: 70 after adjustments } \\
\hline \multicolumn{5}{|c|}{ Trend assumption: Linear deterministic trend } \\
\hline \multicolumn{5}{|c|}{ Series: BUDF BOT CRA GDP INF UNP } \\
\hline \multicolumn{5}{|c|}{ Lags interval (in first differences): 1 to 2} \\
\hline \multicolumn{5}{|c|}{ Unrestricted Cointegration Rank Test (Trace) } \\
\hline Hypothesized & & Trace & 0.05 & \\
\hline No. of CE(s) & Eigenvalue & Statistic & Critical Value & Prob.** \\
\hline None $*$ & 0.466623 & 134.84 & 95.75 & 0.0000 \\
\hline At most $1 *$ & 0.387428 & 90.84 & 69.82 & 0.0004 \\
\hline At most $2 *$ & 0.33244 & 56.53 & 47.86 & 0.0062 \\
\hline At most 3 & 0.174518 & 28.24 & 29.80 & 0.0747 \\
\hline At most 4 & 0.137645 & 14.82 & 15.49 & 0.0630 \\
\hline At most $5 *$ & 0.061636 & 4.45 & 3.84 & 0.0348 \\
\hline \multicolumn{5}{|c|}{ Trace test indicates 4 cointegrating eqn(s) at the 0.05 level } \\
\hline \multicolumn{5}{|c|}{$*$ denotes rejection of the hypothesis at the 0.05 level } \\
\hline
\end{tabular}

Source: calculated from data using Eviews 10 program

As shown in Table 3, we can reject the null hypothesis of "no cointegration at the 0.05 level". As we can notice, there are four cointegrating relationships between the variables, as evident by the trace statistics of 134.84, 90.84, 56.53, and 4.45, which are greater than their corresponding critical values of 95.75, 69.82, 47.86, and 3.84, respectively. In addition, all their probability values are found to be statistically significant at the level of 0.05 . Thus, the empirical findings reinforce the presence of a cointegrating relationship.

\subsection{Estimating the Econometric Model}

Table 4. Estimating economic model, OLS test

\begin{tabular}{|c|c|c|c|c|}
\hline \multicolumn{5}{|c|}{ Dependent Variable: DBUDF } \\
\hline \multicolumn{5}{|c|}{ Method: Least Squares } \\
\hline \multicolumn{5}{|c|}{ Sample (adjusted): 2000Q2 2018Q1 } \\
\hline \multicolumn{5}{|c|}{ Included observations: 72 after adjustments } \\
\hline Variable & Coefficient & Std. Error & t-Statistic & Prob. \\
\hline DGDP & -0.552641 & 0.050699 & -10.9004 & 0.0000 \\
\hline DBOT & 0.024039 & 0.027078 & 0.887777 & 0.3779 \\
\hline
\end{tabular}




\begin{tabular}{lllll}
\hline DINF & $9.98 \mathrm{E}+08$ & $1.12 \mathrm{E}+09$ & 0.894644 & 0.3743 \\
\hline DUNP & $-4.23 \mathrm{E}+09$ & $8.24 \mathrm{E}+08$ & -5.13412 & 0.0000 \\
\hline DCRA & 81082.82 & 41786.48 & 1.940408 & 0.0567 \\
\hline RESID01 & 0.950533 & 0.034178 & 27.81165 & 0.0000 \\
\hline C & 89290405 & 10536167 & 8.474657 & 0.0000 \\
\hline R-squared & 0.943579 & Mean dependent var & -952778 \\
\hline Adjusted R-squared & 0.938371 & S.D. dependent var & $2.16 \mathrm{E}+08$ \\
\hline S.E. of regression & 53634996 & Akaike info criterion & 38.52547 \\
\hline Sum squared resid & $1.87 \mathrm{E}+17$ & Schwarz criterion & 38.74681 \\
\hline Log likelihood & -1379.917 & Hannan-Quinn criter. & 38.61358 \\
\hline F-statistic & 181.1744 & Durbin-Watson stat & 0.566603 \\
\hline Prob(F-statistic) & 0.0000 & \multicolumn{2}{l}{}
\end{tabular}

Source: calculated from data using Eviews 10 program.

Using the OLS estimation technique to test the impact of independent variables on the BUDF, the overall finding indicates that all independent variables are statistically significant, except for BOT, CRA, and INF, with a very low Durbin-Watson at 0.566 . This indicates a positive autocorrelation in the residuals based on the statistical regression analysis. Therefore, we have to add the autoregression model AR (1) in order to address the problem.

Table 5. Estimating economic model, ARMA test

\begin{tabular}{|c|c|c|c|c|}
\hline \multicolumn{5}{|c|}{ Dependent Variable: DBUDF } \\
\hline \multicolumn{5}{|c|}{ Method: ARMA Maximum Likelihood (OPG - BHHH) } \\
\hline \multicolumn{5}{|c|}{ Sample: 2000Q2 2018Q1, Included observations: 72} \\
\hline Variable & Coefficient & Std. Error & t-Statistic & Prob. \\
\hline DGDP & -0.943095 & 0.044142 & -21.3648 & 0.0000 \\
\hline DBOT & -0.099691 & 0.041748 & -2.38794 & 0.0200 \\
\hline DINF & $1.40 \mathrm{E}+09$ & $4.50 \mathrm{E}+08$ & 3.108044 & 0.0028 \\
\hline DUNP & $-5.21 \mathrm{E}+09$ & $3.73 \mathrm{E}+08$ & -13.9629 & 0.0000 \\
\hline DCRA & 207069 & 30036.05 & 6.894016 & 0.0000 \\
\hline RESID01 & 0.826145 & 0.018022 & 45.8403 & 0.0000 \\
\hline $\mathrm{C}$ & $1.34 \mathrm{E}+08$ & 60184605 & 2.225807 & 0.0296 \\
\hline $\operatorname{AR}(1)$ & 0.941857 & 0.063536 & 14.82392 & 0.0000 \\
\hline SIGMASQ & $8.49 \mathrm{E}+14$ & $1.04 \mathrm{E}+14$ & 8.199298 & 0.0000 \\
\hline R-squared & 0.981551 & \multicolumn{2}{|c|}{ Mean dependent var } & -952778 \\
\hline Adjusted R-squared & 0.979208 & \multicolumn{2}{|c|}{ S.D. dependent var } & $2.16 \mathrm{E}+08$ \\
\hline S.E. of regression & 31153021 & \multicolumn{2}{|c|}{ Akaike info criterion } & 37.49348 \\
\hline Sum squared resid & $6.11 \mathrm{E}+16$ & \multicolumn{2}{|c|}{ Schwarz criterion } & 37.77807 \\
\hline Log likelihood & -1340.765 & \multicolumn{2}{|c|}{ Hannan-Quinn criter. } & 37.60678 \\
\hline F-statistic & 418.976 & \multicolumn{2}{|c|}{ Durbin-Watson stat } & 1.938234 \\
\hline Prob(F-statistic) & 0.0000 & & & \\
\hline Inverted AR Roots & 0.94 & & & \\
\hline
\end{tabular}

Source: calculated from data using Eviews 10 program. 
In Table 5, we notice the new results. The value of $\mathrm{R}^{2}$ is found to be 0.981 , indicating that $98.1 \%$ of the changes in budget deficit is explained by the explanatory variables used in the suggested model. The goodness of fit of the regression model is also very high after adjusting the degree of freedom, as revealed by the adjusted $\mathrm{R}^{2}$ value of 97.9\%. There is also a high Durbin-Watson value at 1.938 near 2, which is an acceptable level according to the tabulated value of D-W. This means that residuals are not autocorrelated.

Consequentlyy, we have obtained the estimating model as follows:

$$
\begin{gathered}
\text { DBUDF }=-0.943 * \text { DGDP }-0.099 * \text { DBOT }+1399173317 * \text { DINF }-5209940562 * \text { DUNP }+207068 * \text { DCRA }+ \\
0.826 * \text { RESID01 + } 133959334
\end{gathered}
$$

\section{Evaluating the Quality of Statistical and Standard of the Estimated Model}

In order to verify the quality of the estimated model, we should notice the following:

1. According to Table 5, we notice that the adjusted coefficient $R^{2}$ value has reached 0.981 , which indicates that the independent variables-constitute in the estimated model explained $98.1 \%$ of the changes in the BUDF, and the rest is attributable to other factors.

2. F-test: According to Table 5, F-test value equals 418.97 with a corresponding probability value of 0,000 , which is less than 0.05 . This means that there is a strong and significant relationship between the independent variables and the dependent variable. This leads to the conclusion that the estimating model is good and predictable.

\section{Validating the Suitability of Ordinary Least Square (OLS) Method for This Study}

The following tests examine the suitability of OLS method for this study:

10.1 Testing the Normal Distribution of the Residuals of the Estimated Model

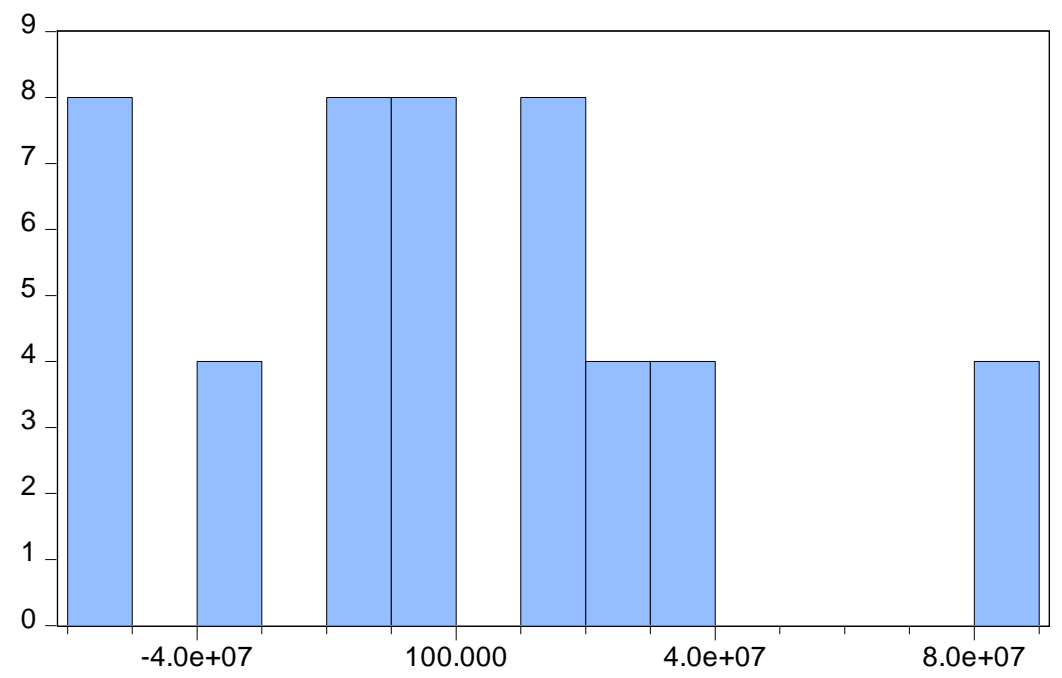

\begin{tabular}{lc}
\multicolumn{2}{l}{ Series: Residuals } \\
Sample 2002Q2 2018Q1 \\
Observations & 72 \\
& \\
Mean & $2.21 \mathrm{e}-07$ \\
Median & -3209669. \\
Maximum & 88629630 \\
Minimum & -59719301 \\
Std. Dev. & 39186011 \\
Skewness & 0.504200 \\
Kurtosis & 3.165776 \\
& \\
Jarque-Bera & 2.088704 \\
Probability & 0.351920 \\
\hline
\end{tabular}

Figure 1. Normal distribution test

Source: calculated from data using Eviews 10 program

The value of Jurque-Bera is 2.08 with a corresponding p-value of 0.351 , which is more than 0.05 , so we can reject the null hypothesis "the data has no normal distribution", meaning the data is normally distributed. 


\subsection{Test for Heteroskedasticity of Errors in Regression}

Table 6. Heteroskedasticity test: breusch-pagan-godfrey

\begin{tabular}{|c|c|c|c|}
\hline \multicolumn{4}{|c|}{ Heteroskedasticity Test: Breusch-Pagan-Godfrey } \\
\hline F-statistic & 0.685134 & Prob. $F(6,65)$ & 0.6622 \\
\hline Obs*R-squared & 4.282656 & Prob. Chi-Square(6) & 0.6385 \\
\hline Scaled explained SS & 12.68948 & Prob. Chi-Square(6) & 0.0482 \\
\hline
\end{tabular}

Source: calculated from data using Eviews 10 program

This test examines whether the variance of the errors from regression is dependent on the values of the independent variables. As Table 6 shows, Obs*R-squared value is 4.28 with a corresponding p-value of 0.638 , which means we can reject the null hypothesis "Homoskedasticity", or "The error variances are all equal," and accept the alternate hypothesis "There is no heteroskedasticity."

\subsection{Variance Inflation Factors-VIF Test}

The variance inflation factor (VIF) is a measure for the amount of multicollinearity in a set of multiple regression variables. This ratio is calculated for each independent variable. A high VIF indicates that the associated independent variable is highly collinear with the other variables in the model. According to Table 7, we notice that the VIF values for all independent variables are below the rules of thumb of 1 or 10 , which means that the variables are moderately correlated (O’brien, 2007).

Table 7. Variance inflation factors

\begin{tabular}{lll}
\hline Independent Variables & $\mathrm{R}^{\wedge} 2$ & Vif $=1 /\left(1-\mathrm{r}^{\wedge} 2\right)$ \\
\hline DGDP & 0.137608 & 1.160 \\
\hline DBOT & 0.085713 & 1.094 \\
\hline DINF & 0.003154 & 1.003 \\
\hline DUNP & 0.002863 & 1.003 \\
\hline DCRA & 0.003672 & 1.004 \\
\hline DGDP & 0.137608 & 1.160 \\
\hline
\end{tabular}

Source: researcher calculated from using $1 /\left(1-\mathrm{r}^{\wedge} 2\right)$ equation

According to all of the above examination, we can confidently notice that the estimated model has fulfilled all the conditions and requirements. Thus, we can rely on it for forecasting and explaining the Palestinian economic condition.

\section{Testing the Hypothesis and Economic Analysis of Estimating Model}

11.1 Testing the First Hypothesis: "There Is No Statistically Significant Relationship at $\alpha \leq 0.05$ Between Budget Deficit and Gross Domestic Product (GDP)."

Going back to Table 5, we can notice that the GDP's coefficient value equals -0.943 , which means a $1 \%$ increase in the gross domestic product. This leads to a $0.941 \%$ decrease in the budget deficit, with a t-statistic value of -21.36 and a $\mathrm{p}$-value of 0.00 , which is less than 0.05 . This means rejecting the null hypothesis and assuring that the GDP is statically significant with budget deficit. This result can be explained as any increase in GDP will lead to an increase in public revenues due to investments, exports, and others, which will lead to a decrease in the deficit.

11.2 Testing the Second Hypothesis: "There Is No Statistically Significant Relationship at $\alpha \leq 0.05$ Between Budget Deficit and Balance of Trade (BOT)."

The coefficient value of BOT equals -0.99 , which means a $1 \%$ increase in the balance of trade will lead to a $0.99 \%$ decrease in the budget deficit, with a t-statistic value of -2.38 and a p-value of 0.02 , which is less than 0.05 , so we can 
reject the null hypothesis and accept the alternative hypothesis "there is a negative relationship." This result can be explained as any increase in BOT will lead to a decrease in the BUDF. This reversed result may be explained due to the Palestinian government's reliance on the taxes and customs imposed on imported goods as a source of revenue. This result is consistents with UNCTAD (2017), which agrees that BOT does not increase the BUDF.

11.3 Testing the Third Hypothesis: "There Is No Statistically Significant Relationship at $\alpha \leq 0.05$ Between Budget Deficit and Inflation Rate (INF)."

Table 5 shows a strong relationship between inflation and budget deficit with a coefficient value of $1.40 \mathrm{E}+09$. This means a one-dollar increase in inflation will lead to an increase of 1400 million dollars in budget deficit. In the other hand, the p-value is 0.0028 , which is less than 0.05 , so we can reject the null hypothesis, and accept the alternative hypothesis "There is a positive relationship." The results mean that inflation worsens the government's fiscal position due to collection lags, which reduces the government's real revenue (Dornbusch, 1990). In itself, this fall in the revenue is accepted as a contributing factor in the inflationary process, through increasing the money supply to finance these inflation-induced deficits (Tanzi, 1991; Aghevli \& Khan, 1978).

11.4 Testing the Fourth Hypothesis: "There Is No Statistically Significant Relationship at $\alpha \leq 0.05$ Between Budget Deficit and Unemployment Rate (UNP)."

According to Table 5, the unemployment rate (UNP) coefficient value is $-5.21 \mathrm{E}+09$, which means an increase of $1 \%$ in the unemployment rate will lead to a decrease of US \$5210 million in the budget deficit. The t-statistic value is - 13.96 with p-value at 0.000; this leads to rejecting the null hypothesis of "no relation" and assuring the negative relationship with the budget deficit.

According to the last unemployment reports, West Bank has a 20.05\% unemployment rate and the Gaza Strip has $40.05 \%$, indicating a high level of unemployment (PCBS, 2019) in the Occupied Palestinian Territory. Unlike other economies, employment in Palestine comprises not two but three categories, as follows: Employment in the domestic economy, employment in Israel and settlements, and unemployment.

The labor gap is the difference between the Palestinian labor force and the number of workers employed in the domestic economy. The labour gap is measured as a ratio of this difference relative to the total labor force (33\%) in 2014. The large budget deficits were financed by foreign aid.

The reliance of the Palestinian economy on foreign aid has substantially increased. The net current transfer (NCT) constituted about one-quarter of the income gap in 1972-1991 and increased steadily following the Palestinian National Authority's establishment, to become over three-quarters of the income gap in recent years. This was a direct result of the decline in the number of Palestinians allowed to work in Israel (UNCTAD, 2017: 22-23).

11.5 Testing the Fifth Hypothesis: "There Is No Statistically Significant Relationship at $\alpha \leq 0.05$ Between Budget Deficit and Current Account (CRA)."

A high coefficient value equals 207069 between the deficit of the current account and budget deficit, which means a one-dollar increase in the current account deficit will increase to 207069 US dollars in budget deficit, with a p-value of 0.00. This leads to rejecting the null hypothesis of "No relationship", and accepting the alternative hypothesis of "A positive relationship" between them. Same results are reached by Darrat (1998), Alkaswani (2000), and Summers (1998) within a framework of what is known in the literature as a current account targeting, which suggested that this relationship is established when a fiscal authority deploys fiscal stances to target the current account ( UNCTAD, 2017:9).

\section{Conclusion}

This study investigates the relationship between fiscal deficit and GDP, BOT, INF, and UNP, as well as CRA in the Palestinian economy, using data collected from the official Palestinian websites for the period 2000-2018. The time series were converted into quarters to increase the observations numbers for obtaining accurate results.

A number of tests were conducted using Eviews10, namely, unit root test, Johansen cointegration test, OLS test, ARMA test, and many other tests to ensure the suitability of the Ordinary Least Square (OLS/ARMA) method for this study.

Johansen test shows the presence of four cointegrating relationship between the budget deficit and the independent variables. Hence, there is a long-run relationship between the budget deficit and other independent variables.

The Adjusted R-squared value is 0.979 , which means that 97.9. \% of the changes in the budget deficit can be explained by the independent variables included in this study. 
There were a few obstacles and limitations the author faced while conducting this study, mostly the lack of the necessary data needed to complete the study. Moreover, during many years, there was political unrest covered by the study, so the author suggested future and similar studies to be conducted on the effect of social development on budget deficit. There is also a possibility of withdrawing from the Paris Economic Agreement, and the role of productive projects in reducing the budget deficit.

The main finding of the study can be summarized as follows:

1. The GDP has a negative statistically significant relationship with the budget deficit, which means a $1 \%$ increase in the gross domestic product, leads to a $0.943 \%$ decrease in the budget deficit. This result can be explained as an increase in the GDP, which leads to an increase in public revenues generated by investments and local taxation. This, in turn, would lead to a decrease in the deficit.

2. There is a negative relationship between BOT and budget deficit. Meaning, a $1 \%$ increase in BOT will lead to a decrease in the budget deficit by $0.099 \%$, as the Palestinian government relies on the taxes and customs imposed on imported goods as a source of revenue to finance the budget deficit.

3. There is a positive and significant relationship between the INF and the BUDF, which means a one-dollar increase in inflation will lead to an increase of 1400 million dollars in budget deficit. The Palestinian government's spending on productive projects was not at the required level, which led to total dependence on imported goods, from abroad and from Israel. This promoted high prices and an increase in the budget deficit as a result of the deficit in the trade balance. The widespread of high prices due to the demand on goods and services, will decrease by the public, which means less revenues for the government generated by taxes and duties.

4. There is a significant negative relationship between unemployment and the BUDF, which means a $1 \%$ increase in the unemployment rate will lead to a decrease of 5210 million US dollars in the budget deficit due to high UNP in West Bank (20.05\%) and the Gaza Strip (40.05\%; PCBS, 2019). This would urge the Palestinian Authority to hire more employees in the public sector to tackle the unemployment issue. In its turn, this would lead to high expenditure as more wages are paid for the additional employees, in addition to the continued closures by Israelis, restrictions on employees' movement, and the increased reliance of the Palestinian economy on foreign aid.

5. There is a strong and positive relationship between the CRA and BUDF, which means a one-dollar increase in the current account deficit will lead to an increase of 207069 US dollars in budget deficit. This relationship is the product of a fiscal authority deploying fiscal stances to target the current account.

\section{Suggestions}

Based on the results, the study recommends:

1. Exploiting foreign grants and aid by the Palestinian Authority for production projects due to their great role in solving the problem of unemployment and increasing the revenues of the government through the imposed taxes on goods and services that would help in decreasing the budget deficit.

2. Adopting austerity policy, reducing expenditures as much as possible, and directing available resources to small projects and industries.

3. Adopting an effective tax policy as a mechanism to reduce tax evasion and the gap between revenues and expenses.

4. Issuing a Palestinian national currency to reduce the effect of the exchange rate on imports and government expenses, according to the Paris Economic Agreement between the Palestine Authority and Israel.

5. Establishing a mechanism to compel Israel to pay the clearance money instead of withholding it.

6. Encouraging investment, especially foreign investment, as it has a positive impact on increasing the revenues of the Palestinian government, solving the problem of unemployment and reducing the inflation rate.

7. Increasing taxes on imported goods that can be produced locally to encourage local industry and reduce imports, which would adjust the trade balance.

8. Increasing the investment spending on projects in order to increase GDP and encourage exports by giving facilities and government support to investors.

9. Attempting to narrow the gap between the total income received by the Palestinians and the income generated by domestic Palestinian production through expanding the Palestinian productive capacity. 
10. Reducing the gap between the total number of the Palestinian labor force and the number of workers employed in the domestic economy.

11. Giving more attention to the agricultural sector by providing technological assistant and support to the farmers.

12. Developing the industry sector and promoting its products to replace imports and boost exports.

\section{References}

Abu Alqumsan, A. (2015). The economic factors affecting the fiscal deficit in the budget Palestinian territories (1995-2013). Unpublished Master dissertation, Islamic University, Gaza, Palestine.

Abu Mustafa, M. (2009). The role and importance of external financing in covering the Permanent deficit Budget for the Palestinian National Authority Comparative analytical study for the period 1999. Unpublished Master dissertation, Islamic University, Gaza, Palestine.

Abu Zaiter, K. (2012). The Role of the local resources in financing the Palestinians government budget suggestions to strengthen the local resources role in financing the budget deficit (2000-2010). Unpublished Master dissertation, Economic and management Science College, Al-Azhar University, Gaza, Palestine.

Aghevli, B., \& Khan, M. (1978). Government deficits and the inflationary process in developing countries. IMF Staff Papers, 25(3), 383-416. https://doi.org/10.2307/3866678

Aljafri, M., \& Alardah, N. (2002). Palestinian financial and trade policies and their impact on the trade balance deficit and the budget deficit. Palestinian Economic Policy Research Institute MAS, MAS publication, Ramallah, Palestine.

Alkswani, M. A. (2000). The twin deficits phenomenon in petroleum economy: Evidence from Saudi Arabia. Presented at the Seventh Annual Conference of the Economic Research Forum. Amman.

Alshaikh, M. (2012). The impact of international aid on economic development in Palestine. A study by Ministry of Planning, Palestinian Authority, Ramallah, Palestine.

Buscemi, A., \& Yallwe, A. (2012). Fiscal deficit, national saving and sustainability of economic growth in emerging economies: a dynamic gmm panel data approach. International Journal of Economics and Financial Issues, 2, 126-140.

Darrat, A. (1988). Have large budget deficit caused rising trade deficits. Southern Economic Journal, 54(4). https://doi.org/10.2307/1059523

Dornbush, R. (1990). Extreme Inflation: Dynamics and Stabilization. In W. C. Brainard, \& G. L. Perry (Eds.), Brookings paper on economic activity. Brookings Institution. https://doi.org/10.2307/2534504

Economic Monitor. (2019). Palestine economic policy research institute. Ramallah, Palestine.

Fakher, H. (2016). The empirical relationship between fiscal deficits and inflation (Case Study: Selected Asian Economies). Iran. Econ. Rev., 20(4), 551-579.

Goher, F., Mehboob, A., \& Wali, U. (2012). Consequential effects of budget deficit on economic growth of Pakistan. International Journal of Business and Social Science, 3(7), 203-208.

Magehema, J. (2015). The effect of budget deficit on economic development in East African countries. Unpublished Master dissertation, School of Business, University of Nairobi Kenya.

Maio, B., Francis, C., \& Venkatesh, S. (2018). The impact of budget deficits on inflation in Zambia. Journal of Economics and Development Studies, 6(2), 13-23. https://doi.org/10.15640/jeds.v6n2a3

MAS- Palestine Economic Policy Research Institute. (2019). 2018 budget performance compared to 2017, and the 2019 clearing revenue crisis. MAS publication, Ramallah, Palestine.

Nguyen, V. (2015). Effects of fiscal deficit and money M2 supply on inflation: Evidence from selected economies of Asia. Journal of Economics, Finance and Administrative Science, 20, 49-53. https://doi.org/10.1016/j.jefas.2015.01.002

O'brien, M. R. (2007). A caution regarding rules of thumb for variance inflation factors. Quality \& Quantity, 41, 673-690. https://doi.org/10.1007/s11135-006-9018-6

Palestinian Central Bureau of Statistics. (2019). The labour force survey results third quarter (July-September, 2019). Palestinian Central Bureau of Statistics publications. 
Palestinian Monetary Authority, Annual Reports. (2000-2011). Research and monetary Policies Department Ramallah, Palestine.

Palestinian Monetary Authority. (2012). Public finance sustainability. Ramallah, Palestine, Palestinian Monetary Authority publications.

Palestinian Monetary Authority. (2015). Public finance sustainability. Ramallah, Palestine, Palestinian Monetary Authority publications.

Palestinian Monetary Authority. (2019). Research and monetary policy department. Annual reports (2012-2018), Ramallah, Palestine.

Summers, L. H. (1998). Tax policy and international competitiveness. In J. A. Frankel (Ed.), International aspects of fiscal policies: National Bureau of Economic Research Conference Report (pp. 349-386). University of Chicago Press, Chicago, United States.

Tanzi, V. (1991). Public finance in developing countries. Edward Elgar Publishing Limited: England.

UNCTAD. (2017). The occupied palestinian territory: twin deficits or an imposed resource gap?, United Nations Conference on Trade and Development, 3-4.

Vuyyuri, S., \& Venkata, S. (2004). Budget deficit and other macroeconomic variables in India. Applied Econometrics and International Development, 4(1), 37-54.

\section{Copyrights}

Copyright for this article is retained by the author(s), with first publication rights granted to the journal.

This is an open-access article distributed under the terms and conditions of the Creative Commons Attribution license (http://creativecommons.org/licenses/by/4.0/). 